\title{
Effects of alfalfa haylage harvesting systems on dry matter intake and feeding behaviour of East Friesland ewes in late pregnancy
}

\author{
Efecto del sistema de cosecha de henilaje de alfalfa sobre el consumo de materia seca y \\ comportamiento del consumo de ovejas Frisón Oriental en el último tercio de preñez \\ HF Elizalde ${ }^{\mathrm{a} *}$, RI Henríquez ${ }^{\mathrm{b}}$

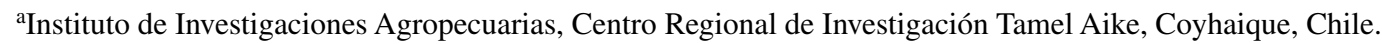 \\ ${ }^{\mathrm{b}}$ Servicios Forestales Alex Carrillo, Coyhaique, Chile.
}

\begin{abstract}
RESUMEN
Tres henilajes fueron confeccionados a partir de un cultivo de alfalfa, segándola y marchitándola por $24 \mathrm{~h}$. La cosecha fue dividida en tres bloques y recogida utilizando la misma cosechadora, ajustando la cantidad de repicadores para producir henilajes con distintos tamaños de picado, es decir henilaje sin repicado (L); repicado simple (S) y repicado doble (D). Los henilajes resultantes fueron de un alto contenido de materia seca (557, 640 y $700 \mathrm{~g} / \mathrm{kg}$ MS), con un largo de picado en promedio de 250, 70 y $20 \mathrm{~mm}$ para L, S y D respectivamente. Veinticuatro ovejas Frisonas, en su último tercio de preñez, fueron asignadas a los tres tratamientos. Los animales tenían acceso a henilaje durante todo el día, con forraje fresco ofrecido diariamente a las $9.00 \mathrm{~h}$. Las ovejas fueron distribuidas en bloques al azar con ocho ovejas por tratamiento y encerradas en corrales individuales. Todas las ovejas recibieron $0,85 \mathrm{~kg} /$ día de concentrado. Los resultados indican que el consumo de MS se ve afectado por el sistema de cosecha de la alfalfa. Las ovejas asignadas al tratamiento L consumieron un $10,7 \%$ y $30,4 \%$ menos materia seca que aquellas que consumían los henilajes S y D, respectivamente. Se observó que las tasas de consumo de las ovejas que consumían henilaje D fueron un $83,2 \%$ y un $218 \%$ más altas que cuando se ofrecía los henilajes $\mathrm{S}$ y L respectivamente. Al final del experimento se observó una mejor condición corporal de los animales que consumían el henilaje preparado con las 12 cuchillas repicadoras (tratamiento D) comparado con el consumo observado para S o L.
\end{abstract}

Key words: haylage, alfalfa, harvesting, ewes.

Palabras clave: henilaje, alfalfa, cosecha, ovejas.

\section{INTRODUCTION}

The effects of the harvesting system used during ensiling on animal performance have been examined in a number of experiments (e.g. Dulphy et al 1984, Dulphy and Van Os 1996, Kononoff et al 2003). These have shown that reductions in silage chop length generally improve dry matter intake, with increased intake reflecting improvements in fermentation in the silo and increases in the rate of passage of material through the digestive tract. Furthermore, it has been demonstrated that sheep are more sensitive to silage chop length than bovines (Allen 1996). For example, intake of long-chopped grass silage by store lambs are generally low, resulting in low liveweight gains (Fitzgerald 1996a, b).

With the recent introduction of alfalfa in Chilean Patagonia (Aysén), its use as silage or haylage has to be reviewed in relation to animal performance. It has been pointed out that forage legumes retain their high intake potential when ensiled (Fraser et al 2000). For example, lambs offered red clover (Speijers et al 2005), or alfalfa (Marley et al 2007) wilted silages had significantly higher

Accepted: 11.03.2009.

* PO Box 296, Coyhaique, Chile; helizald@inia.cl
DM intake and liveweight gain compared to those offered ryegrass silage. In mature ewes, although a beneficial effect of the pre and postpartum feed supplementation using grass silage has been reported (Sepulveda et al 1999, Sepulveda et al 2001, Sormunen-Cristian and Jauhianen 2001), relatively little research has been carried out regarding their effects on voluntary intake and performance of ewes in their pre partum period using this alternative forage.

The objective of this experiment was to evaluate the effects of different alfalfa haylage harvesting systems on dry matter (DM) intake and eating behaviour of East Friesland ewes in late pregnancy.

\section{MATERIAL AND METHODS}

\section{TREATMENTS AND ANIMALS}

The herbage used in this trial was the second cut of an alfalfa (Medicago sativa) sward at the Tamel Aike Research Station (INIA), located in the Simpson Valley, Western Patagonia, Chile $\left(45^{\circ} 45^{\prime} \mathrm{S}\right.$ latitude, $72^{\circ} 02^{\prime} \mathrm{W}$ longitude, $480 \mathrm{~m}$ altitude). The alfalfa sward was cut on March 7th, 2000 , using a mower conditioner and wilted for $24 \mathrm{~h}$. The wilted sward was then divided into three blocks and picked up using different harvesting systems, i.e. long, unchopped haylage (L); single chopped (S) and double-chopped (D) 
haylage. All haylages were harvested using the same forage harvester (Elho, model DC1700 T). The L haylage was produced unchopped, since the forage was blown into the trailer with the edge-cutting flails but having all rotary knives removed; S haylage was harvested with the same harvester but with the rotary chopper-blower fitted with six knives, and $\mathrm{D}$ haylage was harvested with the same harvester but with the rotary chopper-blower fitted with twelve knives. The forage was cut under dry weather conditions and ensiling was completed within $8 \mathrm{~h}$. The three haylages were ensiled in trench silos of $10 \mathrm{~m}^{3}$ capacity. The walls of the silos were lined with plastic sheets prior to ensiling and the ensiled herbage was covered with plastic sheeting immediately after completion and weighed down with a layer of soil.

Twenty four pure bred East Friesian ewes, between 24 and 36 months of age, were oestrus synchronized, following treatment for 14 days, using intra-vaginal pessaries (Chronogest, 20 mg; Intervet Laboratories Ltd). At $48 \mathrm{~h}$ after removal of the sponges, each of the ewes was mated individually with East Friesian rams. All ewes were treated uniformly except the last 6 weeks of pregnancy, when the experimental treatments were imposed.

Ewes were allocated according to live weight and age. This resulted into three groups ( $n=8$ per treatment) with a mean $\mathrm{LW}$ of $75.3 \pm 9.2 ; 75.0 \pm 12.5$ and $75.4 \pm 9.8 \mathrm{~kg}$ for L, S and D treatments.

The animals were housed in individual pens of $1.5 \mathrm{x}$ $1.5 \mathrm{~m}$, arranged in three rows and separated by metal wire partitions. Throughout the experiment, the animals were offered forage ad libitum once daily, with feeding levels designed to ensure a refusal margin of $10 \%$ per day. In addition, ewes received a concentrate supplement that was formulated ( $\mathrm{g} / \mathrm{kg}$ dry weight basis) from oats (577), fish meal (316) and a mineral mix (107). Concentrate was offered at $0.85 \mathrm{~kg} /$ day doses on a dry weight basis, in one daily meal separate from the haylage. Water was freely available at all times from drinking troughs.

Daily subsamples of haylages offered and refused were also taken for chemical composition, and stored at $-20^{\circ} \mathrm{C}$. The subsamples of each haylage was then bulked throughout the week and analyzed for oven dry matter concentration (DM), ammonia $\mathrm{N}, \mathrm{pH}$, crude protein concentration (CP), ash, acid detergent fiber $(\mathrm{ADF})$ and residual water soluble carbohydrates
(WSC). Full details of the analytical procedures used are described by Cushnahan and Gordon (1995). The residual WSC were analyzed as described by Sabag (1988).

The chop length distribution for each of the three haylages was determined by particle size separation. The length of each particle in a $200 \mathrm{~g}$ sample of fresh material was measured, and the particles were separated into four size categories namely: $<50 \mathrm{~mm} ; 51-100 \mathrm{~mm} ; 101-150$ $\mathrm{mm}$ and $>151 \mathrm{~mm}$, as described by Mayne (1983). The dry weight of each category was expressed as a proportion of the total dry weight.

\section{DRY MATTER INTAKE AND FEEDING BEHAVIOUR}

Data was first recorded after a 21 day adaptation period. Fresh haylage was offered daily at $09.00 \mathrm{~h}$. Daily haylage DM intake was calculated on an oven DM basis; and eating rate as described by Forbes et al (1972). All animals were weighed non fasted, with live weight (LW) and body condition scored once per week, according to a scoring scale from 0 to 5 as described by Russel et al (1969).

\section{STATISTICAL ANALYSIS}

Animals were allocated to a complete randomized block design with eight ewes per treatment, three treatments (haylage harvesting system) and eight replicates (ewes).

Condition score was analyzed using a non-parametrical Kruskal-Wallis test, with treatment differences being analyzed according to the Nemenyi multiple range at 0.05 (Walpole and Myers 1992).

Experimental data was subjected to analysis of variance, with treatment differences tested by least significant difference. Haylage composition data was analyzed as a randomized block experiment using the weekly data as replicate.

\section{RESULTS}

\section{CHEMICAL COMPOSITION OF THE SILAGES AND CONCENTRATES AS FED}

The chemical composition of the three haylages offered is presented in table 1. The DM contents of the

Table 1. Chemical composition and mean particle lengths of haylages as removed from the silos.

Composición química y tamaño de partícula de los henilajes, tal como fue ofrecido.

\begin{tabular}{|c|c|c|c|c|c|c|}
\hline & $\mathrm{L}$ & s.e. & $S$ & s.e. & $\mathrm{D}$ & s.e. \\
\hline Dry matter $(\mathrm{g} / \mathrm{kg})$ & $557.0^{\mathrm{a}}$ & 17.9 & $640.0^{\mathrm{b}}$ & 7.6 & $700.0^{c}$ & 5.4 \\
\hline $\mathrm{pH}$ & $5.8^{\mathrm{a}}$ & 0.02 & $5.8^{\mathrm{a}}$ & 0.17 & $5.9^{\mathrm{a}}$ & 0.13 \\
\hline Crude protein (g/kg DM) & $153^{\mathrm{a}}$ & 1.4 & $158^{\mathrm{a}}$ & 1.2 & $156^{\mathrm{a}}$ & 1.8 \\
\hline Ammonia N (g/kg TN) & $175.0^{\mathrm{b}}$ & 16.3 & $199.0^{\mathrm{b}}$ & 18.7 & $118.0^{\mathrm{a}}$ & 14.0 \\
\hline WSC (g/kg DM) & $70^{\mathrm{a}}$ & 1.7 & $79^{\mathrm{b}}$ & 1.9 & $71^{\mathrm{a}}$ & 0.8 \\
\hline Ash (g/kg DM) & $103^{\mathrm{a}}$ & 1.0 & $102^{\mathrm{a}}$ & 0.9 & $105^{\mathrm{a}}$ & 1.8 \\
\hline $\mathrm{ADF}(\mathrm{g} / \mathrm{kg} \mathrm{DM})$ & $319.0^{\mathrm{a}}$ & 4.3 & $308.0^{\mathrm{a}}$ & 2.3 & $325.0^{\mathrm{a}}$ & 17.5 \\
\hline Mean particle length (mm) & 250 & - & 70 & - & 20 & - \\
\hline
\end{tabular}


resulting silages differed markedly, with double-chop haylage $(\mathrm{D}$ treatment) presenting higher $(\mathrm{P}<0.05)$ dry matter content than L treatment haylage, and with the dry matter content of $\mathrm{S}$ treatment haylage being intermediate. The three haylages were similar in terms of crude protein concentration, ADF and ash but the S treatment haylage had a significantly $(\mathrm{P}<0.05)$ higher water soluble carbohydrate content when compared to the other two haylages. The three haylages showed a similar $\mathrm{pH}$ content, however, double-chop haylage presented a lower $(\mathrm{P}<0.05)$ ammonia nitrogen content than the other two haylages.

The chemical composition of the offered concentrate is presented in table 2 .

\section{SIZE DISTRIBUTION OF HAYLAGE PARTICLES}

The size particle distribution of the three haylages are presented in figure 1. Particles of the D haylage were shorter that those of the L haylage, while particles of the $S$ haylage were intermediate having $0.68,0.12$ and $0.42 \%$ of particles shorter than $50 \mathrm{~mm}$, respectively. Conversely, the L haylage and S haylage had 0.54 and $0.09 \%$ of particles longer than $151 \mathrm{~mm}$ respectively, whereas the D haylage had only $0.04 \%$ of particles in this category. The mean particle lengths of the three haylages were 20 $\mathrm{mm}, 70 \mathrm{~mm}$ and $250 \mathrm{~mm}$ for the $\mathrm{D}, \mathrm{S}$ and $\mathrm{L}$ haylages respectively (table 1).

\section{FOOD INTAKE AND FEEDING BEHAVIOUR}

Live weight, feeding behaviour, haylage dry matter intakes and live weight gains of the animals on the individual treatments are shown in table 3 .

Animals offered $\mathrm{L}$ haylage had lower $(\mathrm{P}<0.05)$ eating rate during the first meal than those offered the other two haylages. Compared to haylage L, DM intake of the rotary blower chopped haylages $\mathrm{S}$ and $\mathrm{D}$ was significantly higher ( $\mathrm{P}<0.05$ ) by $10.7 \%$ and $30.4 \%$, respectively.

The condition score evolution of the animals is presented in figure 2. Ewes offered D haylage maintained their CS throughout the experiment and had a significantly $(\mathrm{P}<0.05)$ higher condition score at the end of the experiment than when

Table 2. Chemical composition of the concentrate offered (g/ kg DM, unless otherwise stated).

Composición química del concentrado ofrecido $(\mathrm{g} / \mathrm{kg}$, si no se indica otra cosa).

\begin{tabular}{lrcc}
\hline & Oat & Fish meal & Mineral mix \\
\hline Dry matter & 889.0 & 902.0 & 998.0 \\
Crude protein & 117.0 & 659.0 & - \\
Ash & 14 & 239 & - \\
ME (Mcal/kg) & 2.94 & 2.22 & - \\
P & 9 & 34 & 95 \\
$\mathrm{Ca}$ & 1 & 51 & 150 \\
\hline
\end{tabular}

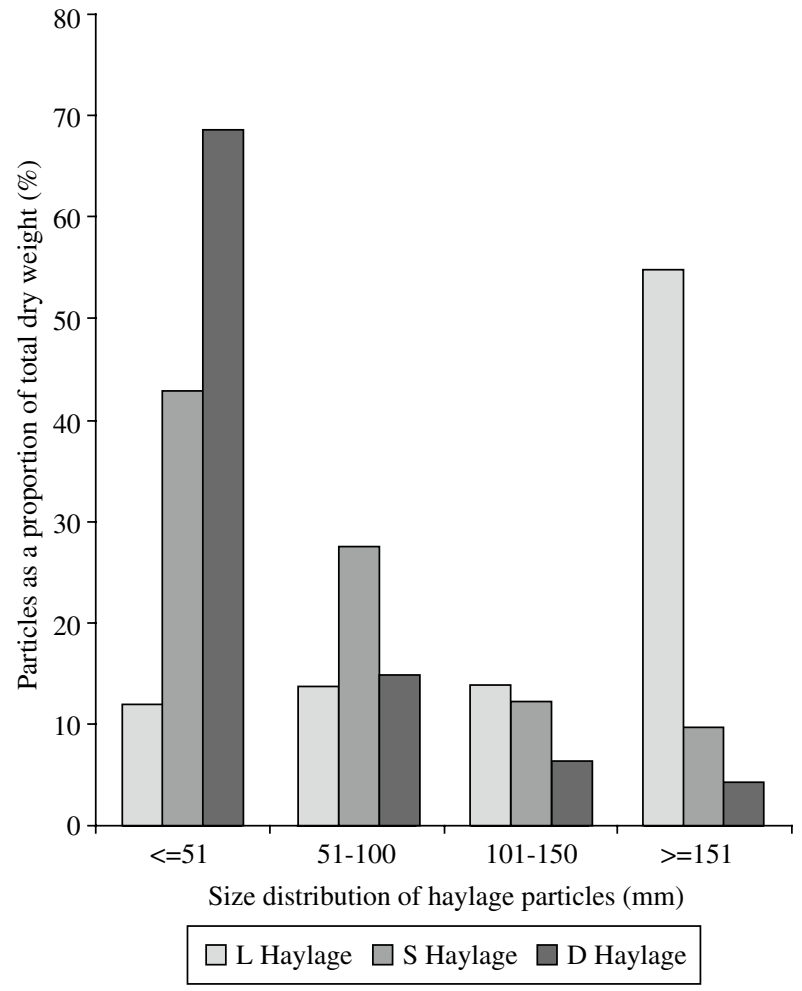

Figure 1. Effect of harvesting system on particle size distribution for the resulting long, unchopped haylage (L); single chopped (S) and double chopped (D) haylage.

Efecto del sistema de cosecha en la distribución del tamaño de partícula de los henilajes sin repicado (L); repicado simple (S) y repicado doble (D).

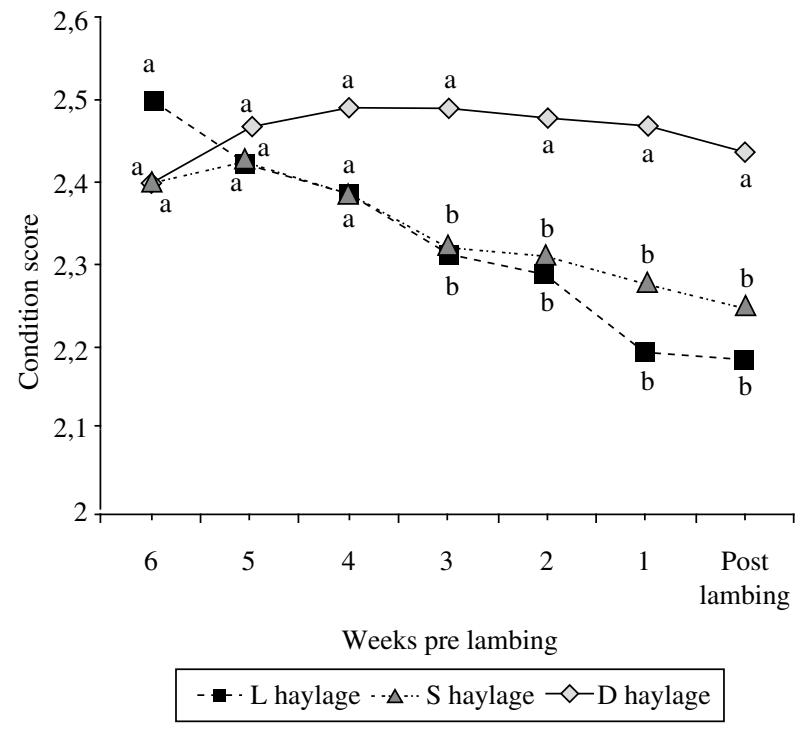

Figure 2. Body condition score evolution of ewes eating long, unchopped haylage (L); single chopped haylage (S) and double chopped (D) haylage.

Evolución de la condición corporal de ovejas alimentadas con henilaje sin repicado (L); repicado simple (S) y repicado doble (D). 
Table 3. Treatment effects on haylage DM intake, feeding behaviour and LW gain.

Efecto de los tratamientos sobre el consumo de MS, comportamiento del consumo e incremento del peso vivo.

\begin{tabular}{|c|c|c|c|c|c|c|}
\hline & $\mathrm{L}$ & s.e. & $\mathrm{S}$ & s.e. & $\mathrm{D}$ & s.e. \\
\hline LW at the start of the experiment $(\mathrm{kg})$ & $75.3^{\mathrm{a}}$ & 3.3 & $75^{\mathrm{a}}$ & 4.4 & $75.4^{\mathrm{a}}$ & 3.5 \\
\hline $\mathrm{L} \mathrm{W}$ at the end of the experiment $(\mathrm{kg})$ & $86.3^{\mathrm{a}}$ & 3.6 & $86.1^{\mathrm{a}}$ & 4.6 & $85.1^{\mathrm{a}}$ & 3.5 \\
\hline Haylage dry matter intake $\left(\mathrm{g} / \mathrm{kg} \mathrm{W}^{0.75}\right)$ & $43.1^{\mathrm{a}}$ & 0.9 & $47.7^{\mathrm{b}}$ & 1.1 & $56.2^{\mathrm{c}}$ & 1.3 \\
\hline $\begin{array}{l}\text { Eating rate during the first meal } \\
\text { (g DM/min) }\end{array}$ & $\begin{array}{r}8.3^{\mathrm{a}} \\
0.30^{\mathrm{a}}\end{array}$ & $\begin{array}{l}0.3 \\
0.03\end{array}$ & $\begin{array}{l}15.2^{\mathrm{b}} \\
0.28^{\mathrm{a}}\end{array}$ & $\begin{array}{l}0.2 \\
0.02\end{array}$ & $\begin{array}{l}18.1^{\mathrm{b}} \\
0.31^{\mathrm{a}}\end{array}$ & $\begin{array}{l}2.1 \\
0.04\end{array}$ \\
\hline
\end{tabular}

offered either S or L haylages, while differences between the last two treatments were not significant $(P>0.05)$ for this parameter at the end of the experiment.

Animal live weights and live weight gains were not significantly $(\mathrm{P}>0.05)$ affected by the harvesting system.

\section{DISCUSSION}

\section{EFFECT OF HARVESTING SYSTEM ON HAYLAGE} COMPOSITION

Physical characteristics. The distributions of particle lengths of the haylages used in the present study are in accordance with results reported by Mayne (1983) and Elizalde (1993) who described the physical characteristics of silages using the same technique of manual particle separation.

The flail-harvested single chop haylage was poorly chopped as expected, with $0.19 \%$ of particles greater than $151 \mathrm{~mm}$ and it was observed that a high proportion of forage, although lacerated, passed through the machine unchopped.

Chemical composition. All three haylages were heavily wilted (> 55\% DM), reflecting a restricted fermentation as described by Muck (1987), with the DM contents of the resulting silages differing by approximately 8 percentage units between $L$ and $S$ haylages, and by 6 percentage units between $\mathrm{S}$ and $\mathrm{D}$ haylages. There were no significant differences in terms of crude protein, ADF and ash content. The high ash content recorded on the three haylages $(103 \mathrm{~g} /$ $\mathrm{kg} \mathrm{DM}$ on average), is attributed to a high degree of soil contamination arising from the suction action of flail - type harvesters (Marsh, 1978), and enhanced by the very dry ground conditions during the harvesting period.

In the present study the $D$ treatment haylage had a better fermentation, indicated by the lower ammonia concentration when compared to $\mathrm{L}$ and $\mathrm{S}$ treatment haylages, suggesting some degree of secondary fermentation and aerobic deterioration in relation to the last two haylages. Similar trends in ammonia concentration were noted by Luchini et al (1997), indicating lower extents of fermentation in alfalfa silages with higher DM.

There were no differences in $\mathrm{pH}$ between the three treatment haylages, with a mean observed value of 5.8.
It has been noted that dry matter level had a pronounced effect on final silage pH (Muck 1987, Muck 1990) since the $\mathrm{pH}$ for ceasing the growth of lactic acid bacteria should increase as DM level increases (Pitt et al, 1985). The overall high final haylage $\mathrm{pH}$ recorded in the present study is reflecting the reduced rate and extent of fermentation obtained in heavily wilted alfalfa haylages, as pointed out by Muck (1990). Furthermore, the higher dry matter content of the haylages resulting from shortchopped harvesting systems is in accordance with early results reported in the literature (Castle 1982, Apolant and Chestnutt 1985), and may reflect the fact that with a higher degree of chopping the cell content is more rapidly liberated, which accelerates the drying rate, resulting in silages with a lower moisture content.

\section{HAYLAGE DRY MATTER INTAKE}

The harvesting system used during ensilage had variable effects on feeding behaviour and dry matter intake.

Ewes offered D haylage had $31 \%$ higher dry matter intake than those offered L haylage and although this difference could be due to a combination of factors, it is likely that it was mainly due to short chopping rather than wilting as reported by Elizalde (1993) in a review which showed that the effects of silage particle length on dry matter intake differ between sheep and cattle, with sheep being more sensitive to silage particle length and less sensitive to the pattern of fermentation of the silage than the cattle. The positive effects of short-chopping on silage consumption have been extensively reported in the literature (Fitzgerald 1996 ${ }^{\mathrm{a}}$, b) and it has been suggested that this effect is due to the fact that silages with a high proportion of long particles are ingested more slowly than silages with short particles. Furthermore, when animals are offered long chop material they first reduce it to fine particles, which probably explains the slow rate of eating (Demarquilly and Dulphy 1977).

In the current trial, the harvesting system showed significant effects in terms of dry matter content of the resulting haylages, with a higher dry matter content being concomitant with a higher degree of chopping. It has been established that DM concentration is a major factor explaining silage intake of dairy cows (Dawson et al 1999, 
Huhtanen et al 2007), which is associated with a faster intake and/or higher turn over rate of ruminal particles. Improved preservation of short-chopped silages compared with long-chopped silages (Fitzgerald $1996^{\text {b }}$ ) may also have contributed to the higher intake and performance on the short-chopped haylages. As reported by Gordon (1986) and later by Petit et al (1993) when comparing the overall effect of system of silage harvesting on animal performance, the present study was designed to evaluate the effect of different haylage harvesting systems, rather than the single effect of one of the factors involved in the harvesting system, therefore it is possible that a reduction in the chop length accompanied with a higher DM concentration may explain the differences observed in dry matter intake.

The increase in haylage DM intake with fine chopping may result partly from improvements in conservation quality obtained by chopping (Dulphy and Demarquilly 1973), although chop length per se is a major factor. For example, chopping of silage just before feeding increases the intake by sheep by 33\% (Dulphy and Demarquilly 1973). Similarly, Fitzgerald $\left(1996^{\mathrm{a}}\right.$ ) reported an increase of $31 \%$ in dry matter intake when double-chopped silages were offered to sheep, in comparison to intake with long, unchopped silage.

Deswysen and Vanbelle (1978) observed that sheep consumed proportionally more silage dry matter than bovines, expressed on a per unit live weight basis, when offered precision chopped silage rather than flail harvested material. According to Demarquilly and Dulphy (1977), the differences between cattle and sheep are due to the smaller diameter of the esophagus and the reticulo-omasal orifice in sheep.

\section{FEEDING BEHAVIOUR}

According to Baumont et al (2000), some physical characteristics of the forage, such as dry matter content and particle size are known to affect ease of prehension and thus intake rate. It has been pointed out that the rate of intake represents the motivation to eat especially at the beginning of the first meal, therefore it seems to be a key factor for understanding variations in voluntary intake between forages (Moseley and Antuna Manendez 1989). For example, Van Os and Dulphy (1995) found, using rumen cannulated wethers, that initial eating rate at the beginning of the meal was depressed by the addition of amines in silage.

In the current study, short chopping of herbage with a double chopped harvester system more than doubled (218\%) eating rate during the first main meal compared with long, unchopped haylage.

The general pattern of consumption observed in the present study was similar to those reported in the literature. For example, Michalet (1975) suggested that the intake of long particle silage was lower than that of short particle material because the latter was ingested more slowly.
When animals are offered long particle silage some long particles reach the rumen, and Demarquilly and Dulphy (1977) concluded that the difficulties in rumination could be due to the presence of these entangled particles and to the fact that the rumen is not properly filled.

Similarly, Deswysen (1980) and Deswysen and Ehrlein (1981), suggested that the physiological reason for pseudo rumination in sheep could be the absence of sufficient small particles of silage in the reticulum for regurgitation, causing a delay in rumination activity. Therefore, although rumination activity was not assessed in the present study, it is probable that an increasing eating rate with the shortchopped silage may partly have resulted from improved rumination, in contrast to what is observed with singlechopped silages.

It seems that the intake of long particle silage is lower than that of short particle length material mainly because it is ingested more slowly. However, the fact that particles leave the rumen at a certain functional density (Teller et al 1990, Kaske et al 1992) when they have been reduced to a critical size (Van Bruchem et al 1991) may also account for the extent of the reduction in silage intake. For example, it takes longer to break down long particle length material, causing a reduction of the rumen outflow rate and consequently, an intake reduction (Teller et al 1990, Van Bruchem et al 1991).

\section{LIVE WEIGHT AND CONDITION SCORE}

All treatments resulted in live-weight gain during the trial. Although no significant differences were detected in terms of liveweight gain between the three haylage harvesting systems, it should be noted that these live-weight gains, including fetal growth, are similar to the average daily growth rates calculated by Rattray et al (1974) and pointed out by Russel (1984) for an acceptable level of feeding on twin bearing ewes. It is interesting to note that ewes eating D haylage were able to maintain their condition score throughout the experiment and had 13\% higher condition score at the end of the experiment than animals eating long, unchopped haylage. With East Friesland ewes in their prepartum period these significant differences are of great importance, reflecting the higher dry matter intake observed.

Gordon (1982) observed that animals offered precisionchopped silage were significantly heavier than the ones eating direct cut silage. Moreover, according to Petit and Flipot (1990), decreasing the silage chop-length decreased the rumen acetate: propionate ratio which suggests that short-chopped silages would be better used for growth rather than milk production.

In conclusion, the results of this study indicate that alfalfa haylage harvesting systems had a marked effect on the dry matter intake of the resulting haylages and the feeding behaviour of ewes. Ewes offered long, unchopped haylage consumed $10.7 \%$ and $30.4 \%$ less dry matter than 
those offered S and D haylage, respectively. These differences in total intake were accompanied by marked changes in eating rate during the first meal, with eating rate of ewes offered D haylage being $83.2 \%$ and $218 \%$ higher than when offered S and L haylage. Animals offered D short-chopped haylage were more able to maintain their condition score throughout their late pregnancy than those offered L or S haylages.

\section{SUMMARY}

Three haylages were produced from the same regrowth of an alfalfa sward by cutting the grass using a mower conditioner and wilted for $24 \mathrm{~h}$. The product was divided into three blocks and picked up using the same harvester, but adjusted to produce haylages differing in chop length, i.e. long, unchopped haylage (L); single chopped (S) and double chopped (D) haylage. The haylages were high in dry matter (DM) content (557, 640 and $700 \mathrm{~g} / \mathrm{kg}$ ), with a mean particle length of 250,70 and $20 \mathrm{~mm}$, for the L, S and D haylages respectively. Twenty four late pregnancy East Friesland ewes were allocated to the 3 treatments. Animals had access to silage throughout the day, with fresh silage being offered daily at $9.00 \mathrm{~h}$. Ewes were allocated to a randomized block design with 8 ewes per treatment and housed in individual pens. All ewes received $0.85 \mathrm{~kg} /$ day of a concentrate supplement. The results of the present study indicate that DM intake was affected by the different alfalfa haylage harvesting systems. Ewes offered L haylage consumed $10.7 \%$ and $30.4 \%$ less dry matter than those offered S and D haylage, respectively. These differences in total intake were accompanied by marked changes in the eating rate during the first meal, with initial eating rates of ewes offered $D$ haylages being $83.2 \%$ and $218 \%$ higher than when offered S and L haylage. A better condition score at the end of the experiment was recorded when animals were offered haylage harvested with 12 knives (D treatment) than when offered $\mathrm{S}$ or $\mathrm{L}$ haylages.

\section{ACKNOWLEDGEMENTS}

The authors would like to thank the skillful staff of the sheep unit at INIA Tamel Aike for their help. We also thank the Analytical Chemistry staff at INIA for carrying out the chemical analyses.

\section{REFERENCES}

Allen MS. 1996. Physical constrains on voluntary intake of forages by ruminants. J Anim Sci 74, 3063-3075.

Apolant SM, DMB Chestnutt. 1985. The effect of mechanical treatment of silage on intake and production of sheep. Animal Production 40, 287-296.

Baumont R, S Prache, M Meuret, P Morand-Fehr. 2000. How forage characteristics influence behaviour and intake in small ruminants: A review. Livest Prod Sci 64, 15-28.

Castle ME. 1982. Making high quality silage. In: Rook JAF, Thomas PC (eds). Silage for milk production. Technical Bulletin $\mathrm{N}^{\circ} 2$. Hannah Research Institute, UK, Pp 127-150.

Cushnahan A, FJ Gordon. 1995. The effects of grass preservation on intake, aparent digestibility and rumen degradation characteristics. Animal Science 60, 429-438.

Dawson LER, CP Ferris, RWJ Steen, FJ Gordon, DJ Kilpatrick. 1999. The effects of wilting grass before ensiling on silage intake. Grass and Forage Sci 54, 237-247.

Demarquilly C, JP Dulphy. 1977. Effect of ensiling on feed intake and animal performance. In: Proceeding of an International Meeting on Animal Production from Temperate Grassland. Irish Grassland Society, Dublin, Ireland.
Deswysen AG, M Vanbelle. 1978. How chopping improves grass silage intake by sheep and heifers. $7^{\text {th }}$ General Meeting of the European Grassland Federation. Gent, Belgium, Pp 619-626.

Deswysen AG. 1980. Intake regulation by sheep and heifers fed silage of different chop length. In: Thomas C (ed.) Proceeding of a Conference of Forage Conservation in the 80's. Occasional Symposium $\mathrm{N}^{\mathrm{o}} 11$. British Grassland Society, Pp 345-349.

Deswysen AG, HJ Ehrlein. 1981. Silage intake, rumination and pseudorumination activity in sheep studied by radiography and jaw movement recordings. British J Nutr 46, 327-335.

Dulphy JP, C Demarquilly. 1973. Influence de la machine de récolte et de la finesse de hachage sur le valeur alimentaire des ensilages. Annales de Zootechnie 22, 199-217.

Dulphy JP, B Michalet-Doreau, C Demarquilly. 1984. Étude comparé des quantités ingérées et du comportement alimentaire et mérycisme d'ovins et de bovins recevant des ensilages d'herbe réalisés selon différentes techniques. Annales de Zootechnie 33, 291-320.

Dulphy JP, M Van Os. 1996. Control of voluntary intake of precision-chopped silages by ruminants: a review. Reprod Nutr Dev 36, 113-135.

Elizalde HF. 1993. Studies on the effects of chemical and physical characteristics of grass silage and degree of competition per feeding space on the eating behaviour of lactating dairy cows. PhD Thesis. Queen's University Belfast, Northern Ireland, United Kingdom.

Fitzgerald JJ. $1996^{\mathrm{a}}$. Grass silage as a basic feed for store lambs. 1. Effect of wilting, chop length and stage of maturity of grass silage on intake and performance of store lambs. Grass and Forage Sci 51, 363-377

Fitzgerald JJ. 1996' Grass silage as a basic feed for store lambs.2. Effect of harvesting system and chop length of grass silage on silage intake and performance of store lambs. Grass and Forage Sci 51, 378-388.

Forbes JM, JA Wright, A Bannister. 1972. A note on rate of eating in sheep. Animal Production 15, 211-214.

Fraser MD, R Fychan, R Jones. 2000. Voluntary intake, digestibility and nitrogen utilization by sheep fed ensiled forage legumes. Grass and Forage Sci 55, 271-279.

Gordon FJ. 1982. The effects of degree of chopping grass for silage and method of concentrate allocation on the performance of dairy cows. Grass and Forage Sci 37, 59-65.

Gordon FJ. 1986. The effect of system of silage harvesting and feeding on milk production. Grass and Forage Sci 41, 209-219.

Huhtanen P, M Rinne, J Nousianen. 2007. Evaluation of the factors affecting silage intake of dairy cows: a revision of the relative silage dry matter intake index. Animal 1, 758-770.

Kaske M, S Hatiboglu, WV Egelhardt. 1992. The influence of density and size of particles on rumination and passage from reticulo-rumen of sheep. British J Nutr 67, 235-244.

Kononoff PJ, AJ Heinrichs, HA Lehman. 2003. The effect of corn silage particle size on eating behaviour, chewing activities, and rumen fermentation in lactating dairy cows. J Dairy Sci 86, 3343-3353.

Luchini ND, GA Broderick, RE Muck, NF Makoni, RL Vetter. 1997. Effect of storage system and dry matter content on the composition of alfalfa silage. J Dairy Sci 80, 1827-1832.

Marley CL, MD Fychan, R Fraser, R Sanderson, R Jones. 2007. Effects of feeding different ensiled forages on the productivity and nutrient-use efficiency of finishing lambs. Grass and Forage Sci 62, 1-12.

Marsh R. 1978. A review of the effects of mechanical treatment of forages on fermentation in the silo and on the feeding value of the silages. New Zeal J Exp Agr 6, 271-278.

Mayne CS. 1983. Studies on field and storage losses occurring during ensilage on the supplementation of grass silage for milk production. $P h D$ Thesis, Faculty of Agriculture, Queen's University Belfast, Northern Ireland, United Kingdom.

Michalet B. 1975. Recherches sur les causes de variations des quantités d'ensilage d'herbe ingerées par les ruminants. These de Docteur Université de Nancy, France.

Moseley G, A Antuna-Manendez. 1989. Factors affecting the eating rate of forage feeds. In: XVI International Grassland Congress, Nice, France, Pp 789-790. 
Muck RE. 1987. Dry matter level effects on alfalfa silage quality. II. Nitrogen transformation. Transactions of the American Society of Agricultural Engineer 30, 7-14.

Muck RE. 1990. Dry matter level effects on alfalfa silage quality. II. Fermentation products and starch hydrolysis. Transactions of the American Society of Agricultural Engineers 33, 373-381.

Petit H, PM Flipot. 1990. Intake, duodenal flow and ruminal characteristics of long or short chopped alfalfa-timothy silage with or without inoculant. J Dairy Sci 73, 3165-3171.

Petit H, GF Tremblay, P Savoie, D Tremblay, JM Wauthy. 1993. Milk yield, intake, and blood traits of lactating cows fed grass silage conserved under different harvesting methods. J Dairy Sci 76, 1365-1374.

Pitt RE, RE Muck, RY Leibensperger. 1985. A quantitative model of the ensilage process in lactate silages. Grass and Forage Sci 40, 279-303.

Rattray PV, WN Garrett, NE East, N Hinman. 1974. Growth, development and composition of the ovine conceptus and mammary gland during pregnancy. J Anim Sci 38, 613-626.

Russel AJF, JM Doney, RG Gunn. 1969. Subjective assessment of body fat in live sheep. J Agric Sci Cambridge 72, 451-454.

Russel AJF. 1984. Means of assessing the adequacy of nutrition of pregnant ewes. Livestock Prod Sci 11, 429-436

Sabag J.1988. Determinación de carbohidratos solubles en diferentes estados fenológicos en Lolium multiflorum y Lolium perenne con Trifolium repens. Memoria de título, Departamento de Educación, Instituto Profesional de Osorno, Osorno, Chile.
Sepúlveda NG, J Oberg, A Neumann. 1999. Efecto de la suplementación con ensilaje a ovejas en gestación y lactación. Arch Zootec 48, 433-436.

Sepúlveda NG, J Risopatrón, J Oberg, A Neumann. 2001. Suplementación pre y post parto en ovejas. Efecto sobre la pubertad y actividad reproductiva de sus hijas. Arch Med Vet 33, 89-96.

Sormunen-Cristian R, L Jauhianen. 2001. Comparison of hay and silage for pregnant and lactating Finnish Landrace ewes. Small Ruminant Research 39, 47-57.

Speijers MHM, MD Fraser, VJ Theobald, W Haresign. 2005. Effects of ensiled forage legumes on performance of store finishing lambs. Animal Feed Science and Technology 120, 203-216.

Teller E, M Vanbelle, P Kamatali, G Collignon, B Page, B Matatu. 1990. Effects of chewing behaviour and ruminal digestion processes on voluntary intake of grass silage by lactating dairy cows. J Anim Sci 67, 3897-3904.

Van Bruchem J, W Marlou, W Bosch, SCW Lammers-Wienhoven, GA Baugma. 1991. Intake, rumination, reticulo-rumen fluid and particle kinetics, and faecal particle size in heifers and cattle fed on grass hay and wilted grass silage. Livest Prod Sci 27, 297-302.

Van Os M, J Dulphy. 1995. The effect of protein degradation products in grass silages on feed intake and intake behaviour in sheep. British J Nutr 73, 51-64.

Walpole R, R Myers. 1992. Probabilidad y Estadística. McGraw-Hill, Mexico, Pp 643-669. 